7.038.53

https://doi.org/10.18485/msc.2018.47.2.ch15

Бојан М. ЈОВИЋ*

Институт за књижевност и уметност Београд
Оригинални научни рад

Примљен: 21. 11. 2017.

Прихваћен: 27. 12. 2017.

\title{
КАРНЕВАЛИЗАЦИЈА И СРПСКА АВАНГАРДА: БЕОГРАДСКА СРЕТЕЊСКА „БАХАНАЛА” 1923. ГОДИНЕ
}

\begin{abstract}
У раду се разматрају основни модалитети присуства карневалске традиције у поетици српске авангарде, који се на најупечатљивији начин сустичу у организацији и извођењу спектакла Хиљаду и друга ноћ, у Београду, 1923. године. Наведени уметнички догађај представља први и једин(ствен)и пример колективног рада авангардних наших стваралаца на општем уметничком делу у нашој уметничкој средини. Изведен непосредно после верског празника Сретење, замишљен је као целовечерњи спектакл са двадесетак провокативних и шокантних тачака удаљених од конвенција грађанске уметности и блиских духу карневала/народне светковине. Као део пропратних промотивних активности, авангардисти посебно за ову прилику издају и новине Поноћ, хумористичко-сатиричног карактера. Заснована на визији битне улоге уметности у друштву, као остварење мултимедијалног колективног дела у коме се текстуални прилози прожимају са музичком основом и наглашеном улогом плеса, Хиљьду и друга ноћ, проткана хумором и провокацијом утемељеним на начелима карневализације, има далекосежни, заједнички (народни) значај, и суштински представља друштвено позитивну, интегративну појаву.
\end{abstract}

Кључне речи: српска авангарда, карневализација, бал Хиљаду и друга ноћ.

Преузимање и оживљавање традиције карневалске културе ${ }^{1}$ у оквирима модернистичких и авангардних стремљења са почетка XX века подстакнуто је општим настојањем нових уметничких покрета да се изведе преврат у уметности и друштву кроз истовремено увођење са једне стране примитивних мисаоних и изражајних форми (Рихтер 1998: 7-21), са друге коренито нових поступака, као и да се обликује основа за нову популарну уметност.

\footnotetext{
*userx64@live.com

${ }^{1}$ Укључивање тема и мотива, структура, облика и жанрова који се у савременом тумачењу историје европске културе и књижевности доводе у везу са карневалским доживљајем света у разматрање актуелних уметничких и књижевних појава изграђено је на претпоставци да постоји континуитет између прастарих ратарских ритуала, античких земљорадничких празника и средњовековних прослава, то јест, да се, кроз европску историју, могу уочити сличности између особина обредно-представљачких форми који у њима владају и одређених уметничких/књижевних поступака и врста (Бахтин 1978: 12).
} 
Карневализација је остварена кроз оживљавање народних светковина, представљачких облика уметности, као и књижевних структура које се везују за нарочите жанрове из области карневализоване књижевности, односно књижевности озбиљно-смешног. ${ }^{2}$ Руски футуристи, пре свих, надахнули су се искуством народнога театра, преносећи своју уметничку делатност на улице, где су, облачећи се у ексцентрична одела, носећи маске и бојећи лица, укључивали публику у представе кроз разговоре, расправе и свађе са њом (Џестровик 2002: 52). При томе су се њихови наступи поклапали са важним датумима у народном календару свјатки, масленица, русалије - Божић, Покладе, Дан мртвих код Старих Словена (Ленквист 1979: 18-9). Поред потраге за примитивним народним уметничким облицима, усмереним ка свечаностима карневалске врсте, европски авангардисти окренули су се и облицима популарног театра, мјузик-холу, водвиљу и кабареу (Боулт 1990: 47-48; Ворден 2012: 149).

Осмишљавање, организација и извођење бала Хиљаду и друга ноћ 1923. године у Београду може се узети за први и практично једин(ствен)и пример рада најширег круга авангардних стваралаца на колективном/општем уметничком делу у нашој средини, оствареном у најбољем духу уметничке карневализације, то јест, као провокативни али друштвено прихватљив/прихваћен забавно-уметнички догађај са јасно одређеним практичним циљевима. ${ }^{3}$ Као такав, бал Хиљаду и друга ноћ, садржећи балет, плес, драмске игроказе, музичке композиције, ликовна дела, филмску пројекцију, књижевна остварења и публикације, ${ }^{4}$ заправо представља мултимедијалну приредбу, замишљену као целовечерњи популарни спектакл. Већ по самом програму јасно удаље-

\footnotetext{
${ }^{2}$ Продор карневалске свести у темељне структуре индивидуалног књижевног стваралаштва узроковао је уобличавање нарочите слике света, праћено обликовањем и развојем низа књижевних жанрова. Ови „карневализовани” књижевни облици - басна, ателана и мим, сатира, менипеја, сократовски дијалог, дијатриба, солилоквијум, симпосион, мемоарска литература, памфлет, пасторална поезија, итд. - често изворно укорењени у древној ритуалној пракси, познати су у теорији и историји књижевности и као жанрови из области „озбиљно-смешног” (

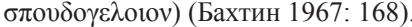

${ }^{3}$ Када је 1922. године један од највећих боема међу српским авангардним књижевницима, Раде Драинац, изнео Браниславу Нушићу, тадашњем начелнику Уметничког одељења Министарства просвете Краљевине СХC, предлог да се организује бал у корист материјално угрожених уметника и књижевника, то се могло учинити као још један у низу провокативних наступа наших авангардиста, у савршеном складу како са Драинчевом животном философијом и поетиком тако и са његовим материјалним стањем. Драинчев је предлог, међутим, на састанцима уметника, књижевника и љубитеља уметности код „Империјала” и у хотелу „Париз” на којима се расправљало како да на најбољи начин заживи Нушићева идеја о оснивању удружења за ширење уметности под именом Удружење пријатеља уметности „Цвијета Зузорић”, названом према запаженој Дубровчанки 16. века, песникињи и надахнућу песника, заштитници уметности и књижевности, прихваћен, али са измењеном наменом - одлучено је да приход од бала иде у корист подизања простор(иј)а за делатност Удружења, будућег Уметничког павиљона „Цвијета Зузорић".

${ }^{4}$ Карневализовани књижевни облици присутни су и независно у нашој међуратној књижевности - узорни модел за можда и најдубље разумевање и најобухватнији распон примене одговарајућих књижевних форми и поступака може се наћи у стваралаштву Растка Петровића (Јовић 2005: 196-256) у последње време, и други модернисти/авангардисти доводе се у везу са овом појавом, на ширем или ужем узорку из њиховог дела (Анђелковић 2017: 63-157). Како било, књижевна карневализација, мада битан састојак међуратних књижевноуметничких стремљења код нас, остаје везана за појединачне покушаје и индивидуалне поетике.
} 
на од конвенција грађанске уметности, изведена непосредно после верског празника Сретење, ова је представа обухватила двадесетак провокативних тачака (уводна поворка Шехерезаде уз пратњу оркестра; потом „Пролог и Епилог” кроз дијалог Арлекина и Шарлоа; „психолошки балет јаве и сна” Собарева метла - Le balai du valet, „купле-сцена” Београде! - Београде! те Баханала Баханткиња и Бахуса...). ${ }^{5}$

\section{Слика 1. Програм бала Хиљаду и друга ноћ}

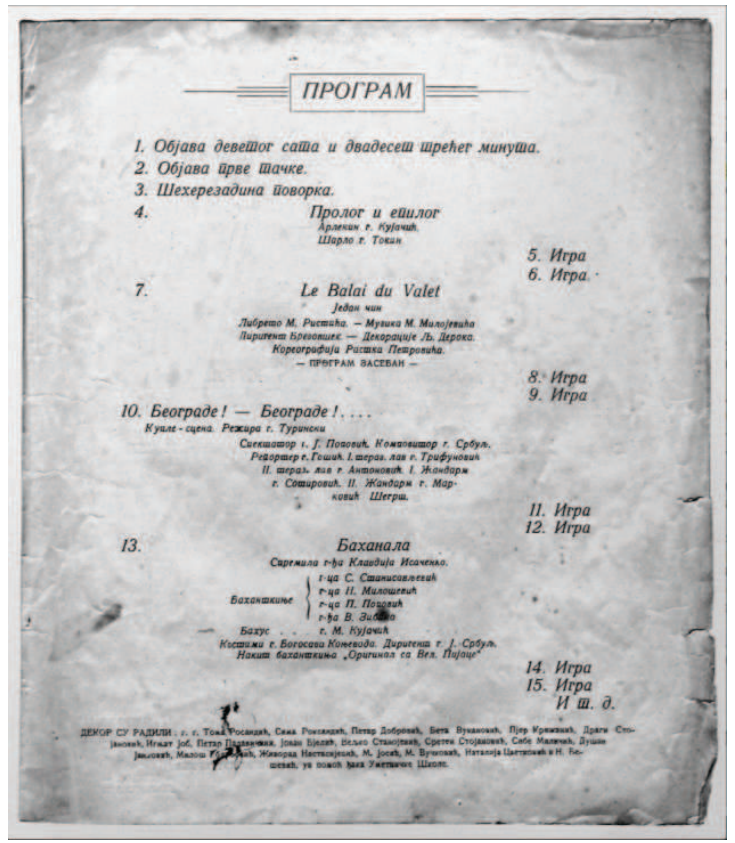

Списак уметника који су узели учешће у припреми или извођењу овога (анти)естетскога и најшире друштвенога догађаја вероватно је један од најдужих у историји одговарајућих авангардних подухвата уопште. За осмишљавање и израду декора били су задужени сликари, вајари и уметници

\footnotetext{
${ }^{5}$ Политика ће тако 16. и 17. фебруара донети вести о балу - први чланак, насловљен Хиљаду u друга ноћ, извештава о припремама за догађај, између осталог правим карневалским језиком истичући постављање карикатура: „Још синоћ су биле постављене велике уметничке карикатуре Универзитета, Народног Музеја итд. а данас ће са једне и друге стране бине бити обешени г. Пашић и Прибићевић, о које су се повешали остали наши политичари” (Политика 5322: 5). Дан касније, под истим насловом, Политикин новинар известиће о великом занимању публике и успеху догађаја, одређујући почетну поворку управо као карневалску: након што се публика једва пробила до сале, „отпочела је свечана поворка Шехерезаде, једна карневалска група са којом је званично отворено вече. И онда је, лагано сасвим лагано, почела да се приближује поноћ. Свет је лагано, сасвим успевао да нађе по који рајски кутак, управо сто и столицу. И ако сте ноћас око два часа наишли кроз просторије „Касине” и „Париза” могли [с]те видети открављена чак и блажена, сасвим блажена лица.

Ситуација се није изменила ни јутрос, у зору. Гужва је била још тако велика, као да нико није пошао кући" (Политика 5323: 5).
} 
Тома Росандић, Петар Добровић, Јован Бијелић, Петар Палавичини и Сретен Стојановић, као и Игњат Јоб, Младен Јосић, Живорад Настасијевић, Никола Бешевић, Милош Голубовић, Александар Дероко, Бета Вукановић, Пјер Крижанић, Душан Јанковић, уз свесрдну помоћ ђака Уметничке школе. Музички део представе обликовали су Станислав Бинички, Милоје Милојевић и Јован Србуљ. Један од плесних делова, балет Собарева метла Милојевића и Ристића, извеле су балерине Народног позоришта, док су у варијететској сали поред професионалних уметника у програму учествовали и Раде Драинац, Бошко Токин, Драган Алексић и Мирко Кујачић. Грађу за књижевну страну догађаја дали су Тодор Манојловић, Марко Ристић и Растко Петровић, који је такође помогао око кореографије Милојевићевог и Ристићевог балета. Новинарско покривање, рекламу и промоцију преузели су са једне стране Бранислав Нушић, Станислав Винавер, Бошко Токин, Ранко Младеновић и Раде Драинац, са друге пак Душан Јанковић.

Широко замишљени „бал”, међутим, није био само скуп за публику атрактивних сцена које обухватају разнородне културне слојеве и области (источњачку традицију, античке дионизијске свечаности, ренесансно позориште, нововековни балет, џез), у извођењу наших многобројних књижевника и уметника - пре свега, осим духа карневализације, који је присутан у свим видовима догађаја, програмске тачке су се међусобно прожимале и одсликавале, одражавајући дубљу, јединствену замисао догађаја и указујући на значења и скривене везе које доводе Бал у контекст сродних међународних појава. Тако ликовни прилози, који најављују и прате Хиљаду и другу ноћ, наглашавају телесно, покрет, еротизам и екстазу, примитивистичка усмерења, иконе савремених уметничких медија. У складу са тим, уметнички плакати Душана Јанковића ("Buffet pour le bal des bohèmes le 16 février 1923 les arts à la mode cubisme art nègre et cinéma" и "Mille et deuxième nuit Cassina 16 février 1923") усмеравају тумачење суштине појаве ка оновременој француској уметничкој сцени, истичући боемске, кубистичке, црначке и кинематографске аспекте, са музичко-сценском компонентом стављеном у први план (оркестар, и разуздани плес и пијанка на једном плакату, нага црначка плесачица на другом).

У том светлу, бал Хиљаду и друга ноћ може се означити као претеча потоњих париских догађаја исте године. Најпре, Драинчева изворна идеја сагласна је са намером париског Савеза руских уметника у Паризу (L'Union des Artistes Russes à Paris) да се организује бал у корист касе узајамне помоћи овог савеза (,,au profit de la caisse de secours mutuel de l'union des artistes russes") (Јовић 2013б: 94). Бал у Паризу, насловљен, са неколиким варијацијама, Велики костимирани заумни бал уметника, односно Велики ноћни бал (Grand Bal des Artistes Travesti Transmental / Grand Bal de Nuit) уз учешће највиђенијих авангардних стваралаца (између осталих, Гончарева, Ларионов, Здањевич, Пикасо, Делоне, Леже, Цара), одржан је у петак 23. фебруара 1923. године, недељу дана након београдског бала Хиљаду и друга ноћ. Потом, октобра 1923. шведски балет изводи Стварање света, „црначки балет”, у чијој су реализацији учествовали неки од најистакнутијих француских 
уметника (сценографију и костиме за ово „примитивно” дело урадио је Фернан Леже, сценарио Блез Сандрар а композицију, под утицајем џеза, Даријус Мијо) (Јовић 2013а: 1056).

Слика 2. Плакат Душана Јанковића за Хиљаду и другу ноћ

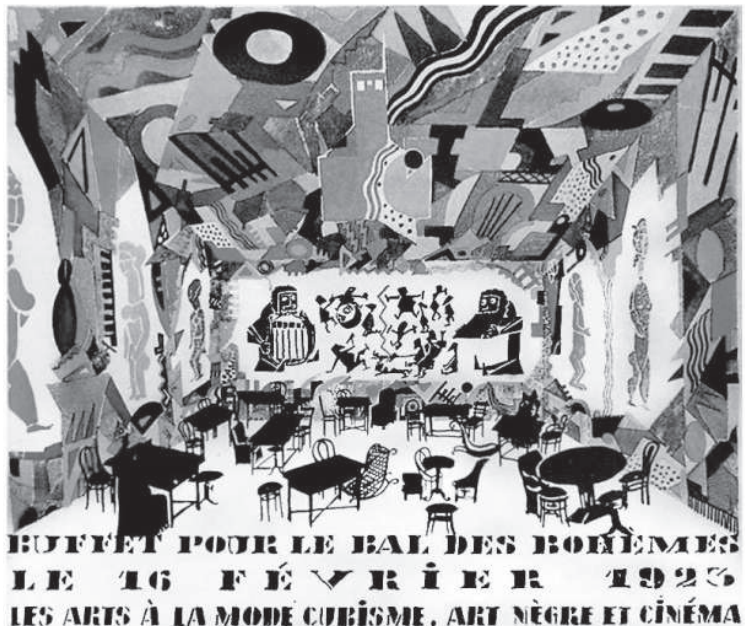

Слика 3. Наирт за плакат Душана Јанковића за Хиљаду и другу ноћ

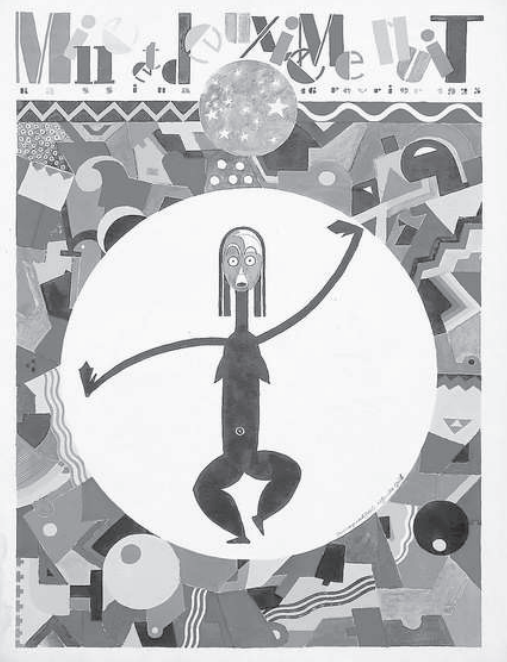

Осим Јанковићевих прилога, Хиљаду и другу ноћ, и у оквиру ње балет $L e$ balai $d u$ valet, оглашава и плакат Александра Дерока, са насмејаном балерином чији су удови представљени наглашено гротескно, у готово приматским цртама; напетост која се при томе јавља између значења балета као плеса који припада високој култури и анимал(изова)не плесачице која га изводи представља естетску провокацију на граници скандала. 
Слика 3. Плакат Александра Дерока за балет Le balai du valet у оквиру Хиљьау и друге ноћи

\section{LEBALADUVALT}

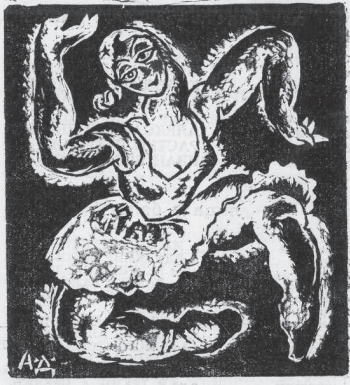

ХИПААУ ИАРУГА HOF

- KACИHA $-16=$ II-1923

И сама Собарева метла, означена као „балетска гротеска” у једном чину, садржи микропоступке обесмишљавања путем алогичности и исмевања кроз Ристићев дадаистичко-протонадреалистички либрето, и Милојевићеву композицију, која колажно обухвата елементе народне музике, фокстрота, валцера, као и цитате градских песама, Вагнера и Штрауса (Милановић 1998: 267; Милин 1999: 70), подривајући и мењајући њихову суштину у духу полистилистичности и наглашеног пародијског презначења.

Слика 5. Фотографија извођача балета Служитељева метла (Le balai du valet) у оквиру Хиљаду и друге ноћи
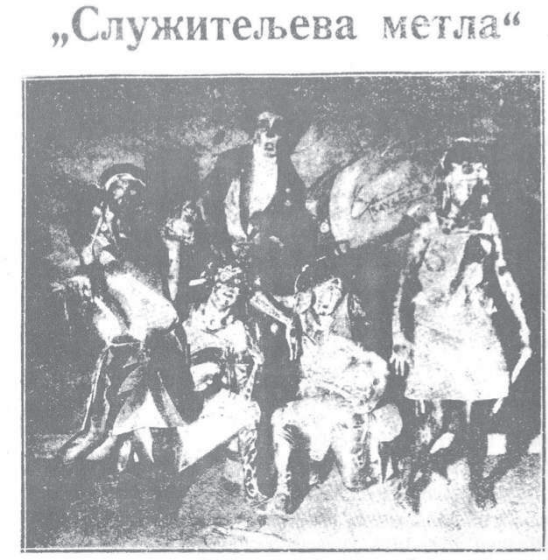

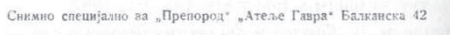

Футуристички балет "Служительева метла“, вал балета у једном чину,

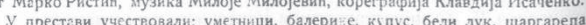
и једаи жив петао... 
Даље, на позивници за бал одштампана је карикатура Чарлија Чаплина, истинске иконе модерних времена, који у том тренутку представља најпопуларнијег планетарног уметника не само из области најмлађе уметности, филма. Осим тога што оличава савремена филмска стремљења слепстик комедије, Чаплинов филмски лик, Мали скитница Чарли/Шарло, призива дугу традицију фолклорних јунака и жанрова популарне представљачке уметности; поред представа из мјузик-холова, водвиља, кабареа и циркуса, Шарло је тако у континуитету (европске) културе у већој или у мањој мери виђен и као наследник митских фигура просјака, скитница, варалица (Либерман 1994: 16-28), настављач кловновске традиције, карневалско-гротескних фигура, ликова из комедије дел'арте, итд. ${ }^{6}$ Са позивнице, ударајући у бубањ, и позивајући на Хиљаду и другу ноћ, Шарло је вишеструко значењски обележен - са једне стране, преиначењем његових атрибута (панталоне сличне арлекиновим, уместо уобичајеног костима Скитнице) наглашава се јасни проширени контекст лика и представе, а са друге се стране наглашено најављује програм(ат)ски врхунац вечери, драмски дијалог са Арлекином.

Слика 6. Позивница за Хиљаду и другу ноћ

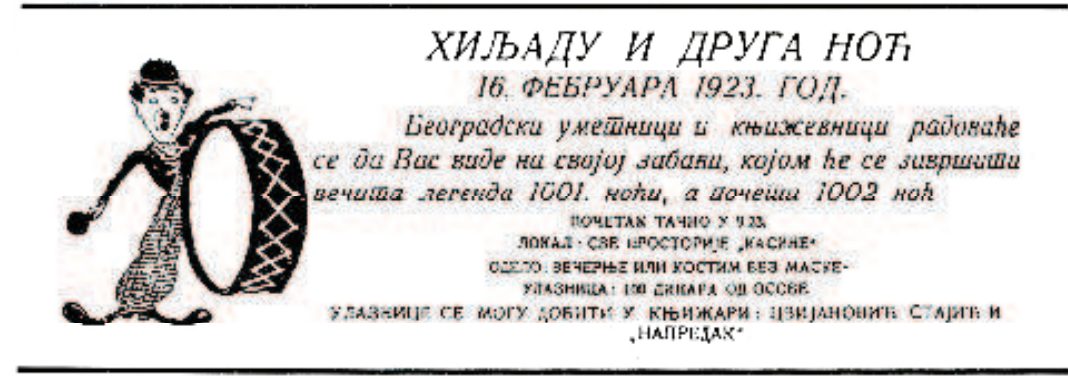

${ }^{6}$ Наведене естетичко-идеолошке особине традиција са којима се доводи у везу Чаплиново филмско и глумачко стваралаштво чине га погодним за примену анализа појава из других области културе и уметности. Није, стога, необично што се, у анализама догодовштина Чаплиновог Скитнице, изглед и карактеризација лик(ов)а, естетика смеха, гротескног, телесног, уметност трга, проблематизовање или преокретање поретка друштвених и моралних вредности неретко уводе и идеје везане за општије културне феномене. Пре свега, то је случај са Бахтиновим разматрањима (Раблеове) карневализоване књижевности, историје романескних модела и смеховне и карневалске културе средњег века. Тако се нпр. истраживање „ниске” уметности код Раблеа види као „драгоцено сочиво за посматрање Чаплина”, а холивудска филмска комедија се, захваљујући нарушавању норми и хијерархије, изједначавањем са „нижим” друштвеним слојевима и одбојној телесности, у целини доводи у везу са Бахтиновим схватањем карневализације. Већ и сам опис распона Чарлијевих послова и занимања показује дубоку сродност са Бахтиновим анализама нарочите средњовековне народне културно-уметничке традиције, оличене у ликовима обешењака, лакрдијаша и луде, који, кроз уметничке облике фаблиоа и шванка, фарсе, пародијских сатиричних циклуса, долазе у сукоб са друштвеном (у случају Бахтинових анализа феудалном) позадином и „ружном” условношћу, са лажи која је прожела све људске односе. Трезвени, весели и лукави ум лакрдијаша (у лику кмета, малограђанина калфе, младог свештеника луталице, то јест, скитнице ван система класа), његово пародијско изругивање и простодушно лудино неразумевање, разоткривају и извргавају руглу поредак лажних и отуђених вредности (Јовић 2012: 23-25). 
У извођењу једног од наших најватренијих чаплиниста, Бошка Токина, Шарло, као бранилац начела животности, новине и модерности (изражавајући се, парадоксално, у симетричном римованом дванаестерцу), ставља се јасно на страну стремљења супротстављених сваком окошталом и тромом приступу уметности и култури који са собом носи „Традиција мртва с разума вампиром", оличена у Арлекину. Осуђујући плеснивост и сивило, и залажући се за радост стварања и откривања новога и животнога, Шарло тако представља узорног гласноговорника авангардистичких и виталистичких тежњи наше послератне уметничке сцене:

ШАРЛО

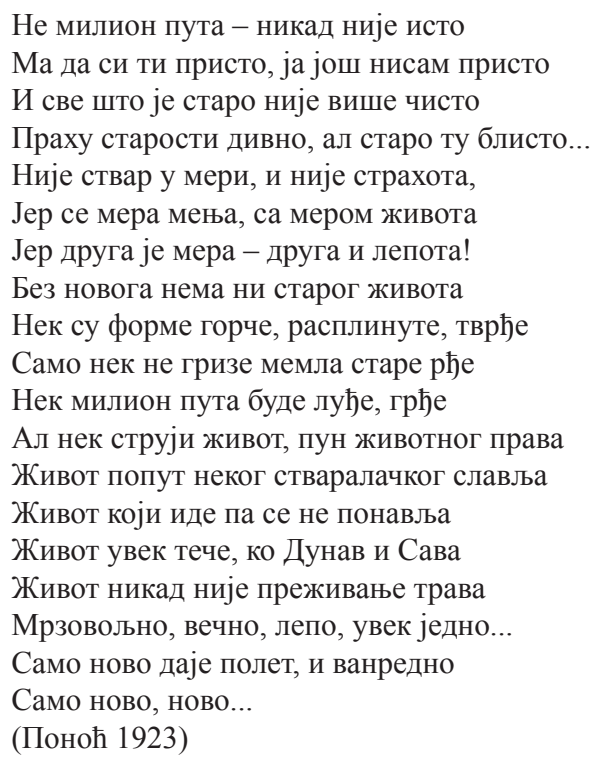

Овај дијалог - „Пролог и Епилог”, као алфа и омега модерности, у целости је пренесен у за ову прилику штампаном посебном (и једином) издању новина Поноћ, број 1002 („Излази по потреби”) хумористичко-сатиричног карактера, за које је Јанковић осмислио заглавље, такође у духу црначке уметности. Означена као „ванпартиски ноћник”, који је направило уредништво под називом „Шехерезадин будоар”, Поноћ одсликава дух менипске сатире, објављујући најразличитије мање новинарске и књижевне облике - сензационалистичке провокативне „вести” из широког распона друштвених питања, почев од високе политике: „Крај свих партијских зађевица на помолу”, „,иновничко питање решено”, „Хрватско питање скинуто са дневног реда”, „Помирење Прибићевића и Пашића”, ,рекламе” (на насловној страни рекламира се филм Трка за мандатом или Секира у меду - велики шлагер из живота политичке иунгле), и „огласе” попут: „Гланц пеглерај и кунст пуцерај - први југословенски завод за фарбање и пеглање Пашић-Прибићевић”, „Државни ауто на продају. Дискреција зајамчена”, „Траже се мандати”... 
Слика 7. Новине Поноћ, са заглављем Душана Јанковића
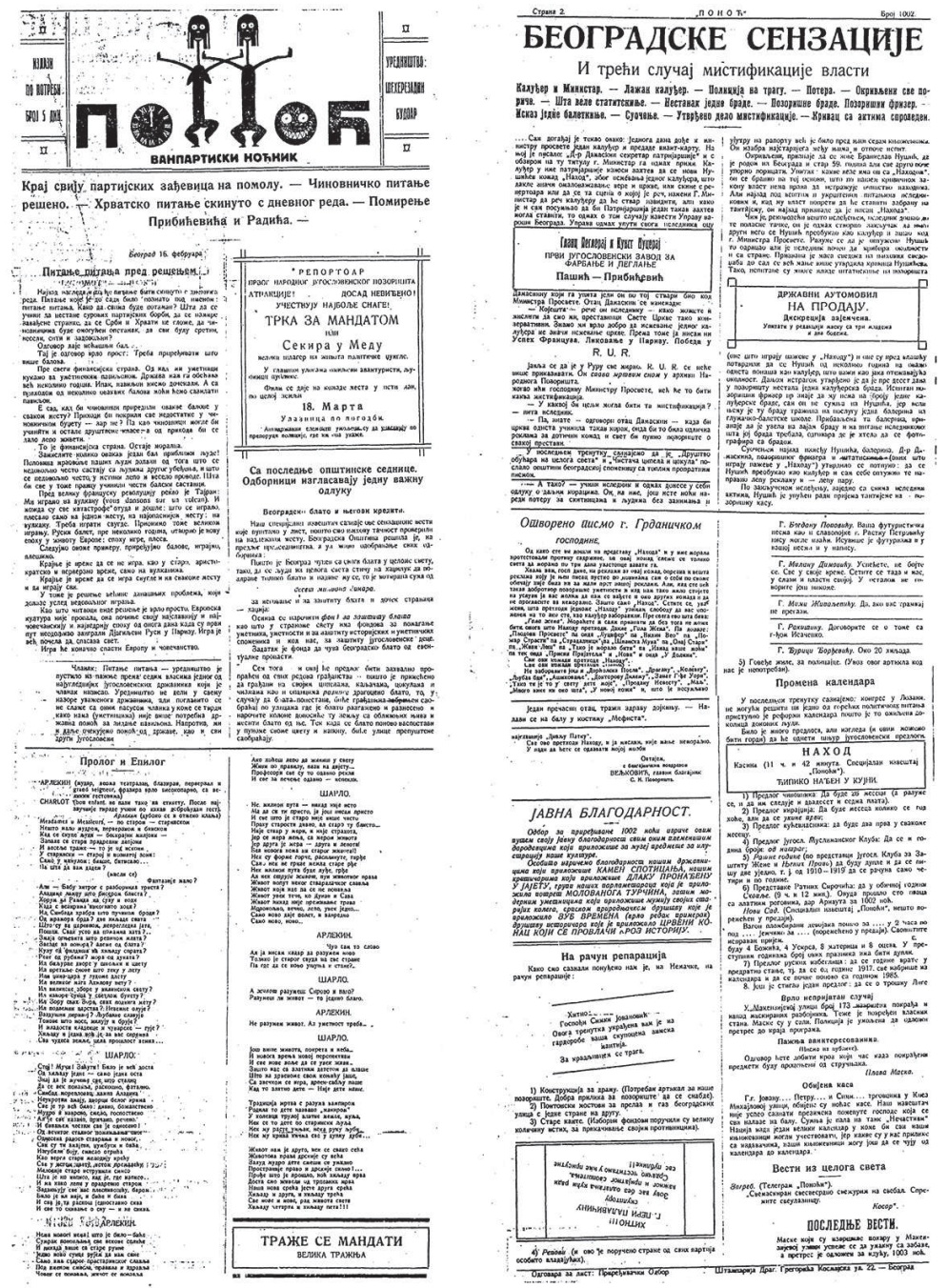

У духу карневалске провокације и друштвене критике, поред усмерености ка политичкој и међунационалној сфери, Поноћ се окреће и према црквеним великодостојницима, сатирично се захваљујући Дамаскину Грданичком, првом секретару Српске Патријаршије, на јавном негодовању у име морала против извођења Нушићеве драме Наход. Овакво иступање види се као најбоља реклама за позоришне представе, те се у име побољшања посете прилаже подужи списак не мање неморалних представа које би у будућности требало критиковати. Даље, текст „Београдске сензације. Трећа мистификација” развија праву травестију на исту тему. Испоставља се да се подноси- 
лац притужбе Министарству просвете на Наход, комад који би требало да се ,због исмевања неког калуђера што дакле значи омаловажавање вере и цркве, или скине с репертоара или се та сцена о којој је реч, измени", лажно представио посетницом као „Д-р Дамаскин секретар патријаршије”. Након разговора са „правим” оцем Дамаскином следи комична полицијска истрага скитница и људи без занимања - то јест књижевника, која на крају, суочавањем „Д-р Дамаскина, позоришног фризера и штатискиња”, показује да се лично Нушић преобукао у свештено лице и сам себе оптужио „те направио лепу рекламу - и лепу пару”. Инверзно хумористичко снижавање присутно је и у одбијању да се корифеју традиционалистичке књижевне критике и науке Богдану Поповићу објаве песма и „славопојке” Растку Петровићу због тога што је „исувише [...] футуризма и у вашој песми и у напису” (Поноћ 1923). ${ }^{7}$

Са уметничке стране, најважнији прилог у новинама у вези са манифестацијом највероватније је текст „Питање питања пред решењем”, у коме је изнесена својеврсна „поетика бала, игре и плеса” српских авангардиста. Бал који се организује види се - кроз шалу и друштвену критику - као модел по коме би требало да се реше сви важнији проблеми у друштву: партијске свађе, међунационални односи, социјалне неправде. Плесна представа такође даје пример могућег превазилажења финансијских проблема, од изградње уметничких павиљона до решавања буџетског дефицита. Са психолошке стране, чешћи балски састанци уклонили би разлоге за мрзовољу наших људи проистеклу из недовољног сусретања са људима другог убеђења, и ретког истински лепог и веселог провода. ${ }^{8}$

Велики бал наших авангардиста, спектакл Xuљаду и друга ноћ, управо је представљао пример таквог „ретког истински лепог и веселог провода” са важним уметничким и друштвеним значењем и последицама. ${ }^{9}$ Одржан у

\footnotetext{
${ }^{7}$ Као нарочита врста карневалског преокретања, снижавања и исмевања живе савремености, истиче се „извештај” о одлуци Београдске Општине да додели суму од десет милиона динара за неговање и заштиту београдског блата, по коме је Београд чувен у свету, и за дочек странаца - хаџија:
}

„Оснива се нарочити фонд за заштиту блата

као што у страноме свету има фондова за помагање уметника, уметности и за заштиту историјских споменика и код нас, за заштиту југословенске деце.

Задатак је фонда да чува београдско блато од евентуалне пропасти” (Поноћ 1923).

${ }^{8}$ Истичући да је са Руским балетом неколико година раније отпочела нова епоха у животу Европе, епоха игре, плеса, аутори позивају да се, сходно томе, и код нас приређују балови, да се игра и плеше, свугде и на свакоме месту, и да играју сви. Текст се закључује коментаром о стању европске културе, која није пропала већ почиње своју неодољиво заиграли Дјагиљевљи Руси у Паризу. По мишљењу аутора, игра је већ почела да спасава свет, и коначно ће спасити Европу и човечанство.

${ }^{9}$ Пре свега, он је био први алтернативни ,бал” у најширем могућем значењу мултимедијалне приредбе, као што је био и први уметнички догађај који је обезбедио значајну суму за почетак изградње здања намењеног уметности. Поред тога, учешће великог броја најзначајнијих уметника најразличитијих праваца (експресионисти, традиционалисти, (прото)надреалисти, дадаисти) поста(ви)ло је не само преседан у њиховим односима већ и (недостижан) узор за свако будуће деловање овакве врсте. И у ширем, међународном, контексту, Хиљаду и друга ноћ такође представља јединствену појаву: иако у суштини авангардистички уметнички догађај, бал је био конкретно подржан од државних органа, имао је практичан финансијски циљ, привукао је неза- 
време значајног верског празника и посебно обележеног датума у српској историји, заснован на визији битне - смеховне, изазивачке, забавне, али и непосредно практичне - улоге уметности у друштву, ово остварење мултимедијалног колективног дела са музичком основом и наглашеном улогом плеса, проткано хумором и провокацијом утемељеним на начелима карневализације, било је стога од далекосежног, заједничког (народног) значаја. ${ }^{10}$

Београдска „сретењска баханала” 16. фебруара 1923. године јасно је оживела дух карневалских светковина, спајајући хуморну критику и сатирично исмевање свих друштвених сталежа: политичара, свештеника, професора, па и самих књижевника, као и уобичајених облика (грађанског) понашања и уметничког изражавања са практичним конкретним циљем. Исказавши и на програмском и на конкретном плану могућности нове естетике, Бал хиљаду друге ноћи остаје један од најзначајнијих тренутака (наше) међуратне културне сцене, тренутак „стваралачког славља” кроз истински карневал у коме су, кроз плес и смех, опречне друштвене и уметничке тежње макар и за тренутак постигле равнотежу.

памћену пажњу јавности, но опет, и поред наглашено провокативног садржаја и форме, није на крају деловао деструктивно већ, напротив, друштвено интегративно.

${ }^{10} \mathrm{У}$ неким приказима, међутим, догађај је оцењен изразито негативно, као, донекле изненађујуће - међутим, можда и даље у карневалском духу преокретања и замене улога - због изразите конзервативности присутне у омладинском гласилу, у тексту „Хиљаду и друга ноћ”, посвећеном Тину Ујевићу и потписаном „Тинов”:

„Хиљаду и друга ноћ. Ноћас се кроз удвостручене маске показала шупљина људска. Зар је нико није видео? [...]

Шестопрста, ледена пест сунчаног Сретења чврсто је и присно стегла ову ноћ. Тамно, хладно, празно, тупо, шупље и ко зна које по реду. Није хиљаду друго.

А у једној светлој кући је тек хиљаду друга ноћ. Светла, шарена, поларна ноћ умова (и душа!) људи шарлатански полуделих, недолуделих - и боема у знаку жандара, свечаног одела или маске и стотинарке. Доћи ће можда и краљ, зато је избачен сваки маљ, а мене не пуштају.

И зашкрипеће зарђале тестере.

И затрубиће аутомобилске трубе.

И замаукаће нешто: мау, мау.

И заклокотаће писаће

И зацвокотаће шиваће машине.

Велика ренесанса шареног и полифоног рококоа. Помешане су немилосрдно и деконцентрично боје у нади да ће се помешати тела. Она се само гурају. Конструисани су најбеззвучнији тонови. Све је у знаку џасбанда, рококоа и гужве. Покушај шарлатански полуделих да шарлатански залуђују. Раде и стомаци. Дакле и морали. Мозгови су се испросипали. Душе су испариле. Све је сувише близу да би се могло желети. Махнитост. Ноћас је велики погреб Уметности. Недолудели уметници недостојни богињопримци створили су својом црношћу у светлости ноћ, светлу, шарену, бледу и млаку, - симбол Велике Лешине, знак Црвоточења. Неки се саркофаг можда отворио и дигао се последњи задах с неке мумије. Не, мумије су непроменљиве и вечите.

Све је испало по програму, само камени лав није сишао са свог каменог подијума, није се ни мрднуо...” (Препород 1923: 4). 


\section{ЛИТЕРАТУРА}

Анђелковић 2017: Н. Анђелковић, Карневал идентитета, Београд: Plato. Бахтин 1967: M. Bahtin, Problemi poetike Dostojevskog, Beograd: Nolit.

Бахтин 1978: M. Bahtin, Stvaralaštvo Fransoa Rabela i narodna kultura srednjeg veka i renesanse, Beograd: Nolit.

Боулт 1990: J. E. Bowlt, Natalia Goncharova and Futurist Theater, Art Journal, vol. 49, no. 1, From Leningrad to Ljubljana: The Suppressed AvantGardes of East-Central and Eastern Europe during the Early Twentieth Century (Spring, 1990), 44-51.

Ворден 2012: C. Warden, British Avant-Garde Theatre, Palgrave Macmillan UK, Basingstoke.

Јовић 2012: Б. Јовић, Јуначи модерних времена. Чарли Чаплин и у очима европске авангарде, Београд: Службени гласник.

Јовић 2013а: Б. Јовић, У потрази за свеобухватним уметничким делом (на неколиким примерима из европске и српске авангарде), Šesti međunarodni interdisciplinarni simpozijum susret kultura 2013, Univerzitet u Novom Sadu, Filozofski Fakultet, II, 1051-1060.

Јовић 2013б: Б. Јовић: Заумна Шехерезада: о београдским и париским (авангардним) баловима између два рата, у: Музикологија, Музиколошки институт САНУ, 14, 93-116.

Ленквист 1979: B. Lönquist, Xlebnikov and Carnival, Stockholm.

Милановић 1998: Б. Милановић, Собарева метла: бликост с европском авангардом, y: В. Перичић (ур.), Композиторско стваралаштво Милоја Милојевића, Београд: Музиколошки институт САНУ, 263-277.

Милин 1999: М. Милин, Први балети југословенских композитора на београдским сценама (1923-1942), Зборник Матице српске за сиенске уметности и музику, бр. 24-25, Нови Сад: Матица српска, 69-77.

Политика 5322: Политика, 16.02.1923, број 5322, 5.

Политика 5323: Политика, 17.02.1923, број 5323, 5.

Поноћ 1923: Поноћ, бр. 1002, Београд, 2003.

Препород 1923: Препород, Лист за живот и културу средњошколске омладине, Гласило „Савеза југослов. средњошколских удружења”, год. V, свеска за март 1923, бр. 3, Београд, 4.

Рихтер 1998: V. Richter, Literary Primitivism: Its Function in the Early Works of Vladimir Mayakovsky and Other Russian Cubo-Futurists, Toronto: University of Toronto.

Џестровик 2002: S. Jestrovic, Theatricality as Estrangement of Art and Life in the Russian Avant-Garde, SubStance, Special Issue: Theatricality, Issue 98/99, vol. 31, no. $2 / 3,42-56$. 
Bojan M. Jović

\title{
CARNIVALIZATION AND SERBIAN AVANT-GARDE: BELGRADE "BACCHANALIA" ON THE FEAST OF THE PRESENTATION IN THE TEMPLE, 1923 A.D.
}

\author{
(Summary)
}

The paper deals with the basic modalities of the presence of carnival tradition in the poetics of the Serbian avant-garde, which in the most striking way coincide with the organization and performance of the spectacle "Thousand and Second Night Ball", in Belgrade, 1923. The mentioned artistic event represents the first and only example of the collective work of Serbian and Yugoslav avant-garde artist and writers. Conducted immediately after the religious Feast of Sretenje (The Presentation of Jesus at the Temple), it is conceived as a full-length spectacle with twenty provocative and shocking numbers away from the conventions of bourgeois art and it's impregnated with spirit of the carnival / national feast. As part of accompanying promotional activities, avant-gardists, especially for this occasion, also published The Midnight, a newspaper of humorous-satirical character. Based on the vision of the essential role of art in society, as the realization of multimedia collective work in which textual contributions are interwoven with the musical basis and the pronounced role of dance, the "Thousand and Second Night Ball", bursting with humor and provocation based on the principles of carnivalization, has a farreaching significance, and essentially represents a socially positive, integrative phenomenon. 